\title{
International Interdependence and the Welfare Effects of Monetary Policy ${ }^{*}$
}

\author{
WOLFRAM BERGER \\ University of Hagen \\ Department of Economics, ESG \\ Universitätsstrasse 41 \\ 58084 Hagen \\ Germany \\ Email: wolfram.berger@fernuni-hagen.de \\ Phone: ++49-2331-987-2416 \\ Fax: ++49-2331-987-391
}

October 2003

\begin{abstract}
Several economic distortions are integrated into a fully dynamic general-equilibrium framework to investigate the welfare effects of monetary policy. The model considers intermediate goods and two consumption good sectors that rely to different degrees on inputs from abroad. We further assume that an equal input bias in the production of consumption goods exists in the world. The welfare effects of monetary policy in the home and the foreign country crucially depend on their degree of interdependence and the competitiveness of markets. Monetary policy may have adverse beggar-thyself effects if the mutual dependence is considerably high. The foreign country benefits from a home monetary expansion unless the competitiveness of markets is too low.
\end{abstract}

JEL Classification: F31, F32, F41, F42

Keywords: intermediate goods, monetary policy, input bias, beggar-thy-neighbor, prosper-thyneighbor

\footnotetext{
* This paper was presented at the EEFS annual conference in Bologna (May 2003) and the annual conference of the Verein für Socialpolitik (German Economic Association) in Zürich (October 2003). Helpful comments from seminar participants are gratefully acknowledged.
} 


\section{$1 \quad$ Introduction}

A central issue in international macroeconomics is the welfare effects of monetary policy. What the welfare consequences for domestic agents are, and how monetary adjustments are transmitted to other economies, are key questions in this respect. The conventional wisdom that an expansionary monetary policy is beneficial for the expanding country and detrimental for the rest of the world, has been questioned and qualified in recent theoretical work by Obstfeld and Rogoff (1995, 1996). In their studies, an expansionary monetary policy anywhere in the world benefits all countries equally. Monetary policy thus does not generate the familiar beggar-thy-neighbor effects but rather, prosper-thy-neighbor effects. Several papers have since modified the Obstfeld and Rogoff framework through the consideration of, e.g., non-traded goods (Hau 2000), a limited pass-through of exchange rate changes (Betts and Devereux 1996, 2000), different degrees of substitutability between varieties of home goods and between domestic and foreign goods (Corsetti and Pesenti 2001a, Tille 2001), a home bias (Michaelis 2002, Warnock 2003) and a production process consisting of more than one stage through the inclusion of intermediate goods (Obstfeld 2001, Bacchetta and van Wincoop 2002) or distribution services (Tille 2000). Beggar-thy-neighbor effects re-appear in a number of these models. Even the possibility of a detrimental beggar-thyself effect for the expanding country emerges (see, e.g., Tille 2001).

In this paper, a framework is presented that tries to capture the logic and the implications of several of these features and that allows for an explicit exploration of their interaction. We suppose that the production process consists of more than one stage. Each country produces a continuum of differentiated intermediate goods. These intermediate goods are used to produce consumption goods in two sectors that to different degrees rely on inputs from abroad. By altering the relative size of the consumption goods sectors the openness of the economies can be varied. An "input bias" in the production of consumption goods might prevail, implying that for given relative prices home consumption goods firms demand relatively more home produced inputs than foreign consumption goods firms. Thus, the model allows for a variation in the interdependence of the economies.

Both the assumption of two consumption goods sectors with a different need for inputs from abroad and the input bias limit the responsiveness of domestic prices to exchange rate changes. Exchange rate fluctuations may be completely passed-through to import prices but hardly affect consumer prices and the CPI. This is in accordance with the results of empirical 
work (see references given below). Basically, our approach accounts for two stylized facts that emerged from the empirical literature. First, prices move less than one to one with the exchange rate and second, consumer prices are much less affected than import prices. In fact, the pass-through to consumer prices has been found to be close to zero. ${ }^{1}$ A low pass-through to consumer prices of course means that exchange rate changes do not give rise to a considerable redirection of global consumption spending. But, exchange rate movements may lead to a substitution effect on the firm level. Obstfeld (2001) points out that sourcing decisions by firms are to be considered as a major channel through which exchange rate movements influence trade flows and, hence, aggregate demand for countries' outputs. Following this argument, in this model the effects of monetary adjustments and exchange rate changes originate in the firm level.

In our model, the results crucially depend on three parameters. The input bias in the production of final commodities, the relative size of the consumption goods sectors and the elasticity of substitution between home and foreign input goods are key for the macroeconomic effects and the welfare implications of a monetary policy change. Consequently, the focus of our analysis lies on the impact that different values of the model's key parameters have on the model's results.

The model's main results can be summarized as follows. Generally, the impact of a home monetary policy change is not unambiguous for both the home and the foreign country. An expansionary monetary policy is more likely to be beneficial for the expanding country (prosper-thyself) the less open the economy is and the less dependent the economy is on inputs from abroad. Moreoever, the more competitive markets are (i.e. the greater the substitutability between home and foreign goods), the more likely is a prosper-thyself effect of monetary policy. A detrimental effect of an expansionary monetary policy on the expanding country's welfare (beggar-thyself) is possible for a relatively open economy that is strongly linked to the rest of the world. Comparatively large monopolistic distortions increase the probability of an adverse beggar-thyself effect. The rest of the world most likely benefits from a home monetary expansion (prosper-thy-neighbor). Only in the case of a high degree of

\footnotetext{
${ }^{1}$ See, e.g., Engel and Rogers (1996), Parsley and Wei (2001) and McCarthy (1999) for evidence on pass-through to consumer prices and, e.g., Goldberg and Knetter (1998) and Campa and Goldberg (2002) for evidence on pass-through to import prices. See Goldberg and Knetter (1997) for a review of the literature and Engel (2002) for a review of new approaches in the theoretical literature.
} 
substitutability between home and foreign goods does the familiar beggar-thy-neighbor effect become possible.

The rest of the paper is organized as follows. In the next section the model is developed. In section 3 the model is log-linearized around an initial steady state. Section 4 presents the closed form solutions and section 5 is devoted to the welfare analysis of monetary policy. The effects of money supply changes on home and foreign welfare are derived and a numerical example is presented. Section 6 concludes.

\section{A Two-Country Model}

The world economy consists of two equally sized countries inhabited by a continuum of household and of intermediate and final goods firms of mass one. Agents over the $[0,1]$ interval live in the home country, while agents in the $[1,2]$ interval are residents of the foreign country. Analogously, goods over the $[0,1]$ interval are produced in the home country while goods in the $[1,2]$ interval are produced in the foreign country. In the following sections, only the equations for the representative home agent and the representative home firm are presented. Mirror images hold for the foreign country (the equations for the foreign country are given in Appendix A).

\section{$2.1 \quad$ Households}

The intertemporal utility of the representative home agent is given by a time seperable utility function with a unitary elasticity of intertemporal substitution.

$$
\mathrm{U}_{\mathrm{t}}=\sum_{\mathrm{s}=\mathrm{t}}^{\infty} \beta^{\mathrm{s}-\mathrm{t}}\left[\log \mathrm{C}_{\mathrm{s}}+\chi \log \frac{\mathrm{M}_{\mathrm{s}}}{\mathrm{P}_{\mathrm{s}}}-\frac{\kappa}{2} \mathrm{~h}_{\mathrm{s}}{ }^{2}\right] \text {, }
$$

where $\beta, 0<\beta<1$, is the discount rate. $\mathrm{C}$ denotes a consumption index defined below; $\mathrm{M}$ denotes the domestic money stock, $\mathrm{P}$ is the consumer price index (also defined below) and $\mathrm{h}$ is the hours worked.

Consumption goods are produced in two sectors denoted by I and II. Let $\mathrm{C}_{\mathrm{t}}^{\mathrm{i}}$ denote the consumption good produced in sector i= I, II. Households' preferences over the sectorspecific consumption goods are given by 


$$
\mathrm{C}_{\mathrm{t}}=\lambda\left(\mathrm{C}_{\mathrm{t}}^{\mathrm{I}}\right)^{\mathrm{t}}\left(\mathrm{C}_{\mathrm{t}}^{\mathrm{II}}\right)^{1-\mathrm{t}}
$$

where $\lambda=\mathrm{t}^{-\mathrm{t}}(1-\mathrm{t})^{1-\mathrm{t}}$. The Cobb-Douglas aggregation implies that the substitution elasticity between goods from sectors I and II is equal to one. The consumer price index (CPI) defined as the minimum money expenditure required to purchase one unit of the consumption basket can then be derived as

$$
\text { (3) } \quad P_{t}=\left(P_{t}^{I}\right)^{t}\left(P_{t}^{I I}\right)^{1-t} \text {, }
$$

where $\mathrm{P}_{\mathrm{t}}^{\mathrm{i}}$ denotes the price of the consumption good from sector $\mathrm{i}=\mathrm{I}$, II . Households' demand for the consumption goods from both sectors is:

(4) $\mathrm{C}_{t}^{\mathrm{I}}=\mathrm{t}\left[\frac{\mathrm{P}_{\mathrm{t}}^{\mathrm{I}}}{\mathrm{P}_{\mathrm{t}}}\right]^{-1} \mathrm{C}_{\mathrm{t}}, \quad$ and $\quad \mathrm{C}_{\mathrm{t}}^{\mathrm{II}}=(1-\mathrm{t})\left[\frac{\mathrm{P}_{\mathrm{t}}^{\mathrm{II}}}{\mathrm{P}_{\mathrm{t}}}\right]^{-1} \mathrm{C}_{\mathrm{t}}$.

Households hold two assets, domestic money, $\mathrm{M}_{t}$, and a riskless real bond, $\mathrm{B}_{\mathrm{t}}$, which is denominated in terms of the consumption index $C_{t}$. With $r_{t}$ being the bond's real rate of return (between periods $\mathrm{t}-1$ and $\mathrm{t}$ ), households' intertemporal budget constraint is:

$$
\mathrm{M}_{\mathrm{t}}+\mathrm{P}_{\mathrm{t}} \mathrm{B}_{\mathrm{t}+1}=\mathrm{W}_{\mathrm{t}} \mathrm{h}_{\mathrm{t}}+\pi_{\mathrm{t}}^{\text {final }}+\pi_{\mathrm{t}}^{\text {int er }}+\mathrm{M}_{\mathrm{t}-1}+\left(1+\mathrm{r}_{\mathrm{t}}\right) \mathrm{P}_{\mathrm{t}} \mathrm{B}_{\mathrm{t}}-\mathrm{P}_{\mathrm{t}} \mathrm{C}_{\mathrm{t}}-\mathrm{P}_{\mathrm{t}} \mathrm{T}_{\mathrm{t}}
$$

Nominal wealth carried over into the next period consists of nominal balances and bonds (1.h.s. $)^{2}$ and is derived from labor income where $\mathrm{W}_{\mathrm{t}}$ is the domestic nominal wage, from wealth at the beginning of period $t\left(M_{t-1}+\left(1+r_{t}\right) P_{t} B_{t}\right)$ and from the agents' (equal) share of (nominal) profits from final and intermediate goods firms $\left(\pi_{t}^{\text {final }}+\pi_{t}^{\text {int er }}\right)^{3}$, less the expenditure for consumption and taxes. $\mathrm{T}_{\mathrm{t}}$ denotes real lump-sum taxes in terms of the consumption index $\mathrm{C}_{\mathrm{t}}$.

Maximizing lifetime utility subject to the budget constraint (5) yields agents' optimal choices.

\footnotetext{
${ }^{2}$ Following the notation of Obstfeld and Rogoff (1995), $\mathbf{M}_{\mathrm{t}}$ denotes the stock of money held by a household entering period $\mathrm{t}+1$.

${ }^{3}$ For simplicity it is assumed that all firms are wholly owned by the residents of the country they are located in.
} 


$$
\mathrm{C}_{\mathrm{t}+1}=\beta\left(1+\mathrm{r}_{\mathrm{t}+1}\right) \mathrm{C}_{\mathrm{t}}
$$

$$
\frac{\mathrm{M}_{\mathrm{t}}}{\mathrm{P}_{\mathrm{t}}}=\chi \mathrm{C}_{\mathrm{t}} \frac{1+\mathrm{i}_{\mathrm{t}+1}}{\mathrm{i}_{\mathrm{t}+1}},
$$

$$
h_{t}(i)=\frac{W_{t}}{k P_{t} C_{t}}
$$

Equation (6) is the familiar Euler equation for the optimal intertemporal consumption path. Equation (7) gives the consumption based money demand, where $i_{t}$ denotes the nominal interest rate which is defined as $\left(1+\mathrm{i}_{\mathrm{t}}\right)=\left(1+\mathrm{r}_{\mathrm{t}}\right) \mathrm{P}_{\mathrm{t}+1} / \mathrm{P}_{\mathrm{t}}$. At the margin, households are indifferent between spending their ressources for a further unit of $\mathrm{C}$ and holding them as real balances. Equation (8) reflects the optimal labor supply. The marginal disutility of providing an extra hour of work must equal the marginal utility of consuming the additional earnings.

\subsection{Firms and market structure}

We differentiate between final consumption goods and the intermediate goods needed to produce them. ${ }^{4}$ In both countries, intermediate goods producers enjoy a degree of monopoly power. Both countries operate the same technology. The production of a differentiated intermediate good only requires labor input, $\mathrm{y}_{\mathrm{t}}=\mathrm{h}_{\mathrm{t}}$. Since the production technology is identical for all firms and the elasticity of demand is the same in all intermediate goods markets, all producers behave identically to one another. They produce the same amount of goods and charge the same price. Output and prices can therefore be interpreted as representative and hence indexes are omitted most of the time.

The final commodities are competitively produced by bundling a continuum of differentiated intermediate goods. The two consumption goods sectors can be distinguished by the inputs required in the production process. While in sector I both home and foreign intermediate goods need to be combined to produce a sector-I-consumption good, producers in sector II only need the intermediate goods of their respective country, i.e. no input from abroad is required.

\footnotetext{
${ }^{4}$ Intermediate goods are also considered by, e.g., Chari, Kehoe and McGrattan (2002) and Obstfeld (2001).
} 
(9) $\quad \mathrm{Y}_{\mathrm{t}}^{\mathrm{I}}=\left[\alpha^{\frac{1}{\gamma}}\left(\mathrm{y}_{\mathrm{t}}^{\mathrm{h}}\right)^{\frac{\gamma-1}{\gamma}}+(1-\alpha)^{\frac{1}{\gamma}}\left(\mathrm{y}_{\mathrm{t}}^{\mathrm{f}}\right)^{\frac{\gamma-1}{\gamma}}\right]^{\frac{\gamma}{\gamma-1}} \quad$ and $\quad \mathrm{Y}_{\mathrm{t}}^{\mathrm{II}}=\mathrm{y}_{\mathrm{t}}^{\mathrm{h}}$.

Following Obstfeld (2001) and Chari, Kehoe and McGrattan (2002), we assume that final commodities are nontradeable (all trade is in intermediate goods). Thus, in equilibrium we have $\mathrm{Y}_{\mathrm{t}}^{\mathrm{I}}=\mathrm{C}_{\mathrm{t}}^{\mathrm{I}}$ and $\mathrm{Y}_{\mathrm{t}}^{\mathrm{II}}=\mathrm{C}_{\mathrm{t}}^{\mathrm{II}} \cdot \mathrm{y}_{\mathrm{t}}^{\mathrm{h}}\left(\mathrm{y}_{\mathrm{t}}^{\mathrm{f}}\right)$ is a basket of home (foreign) produced intermediate goods. $\gamma(\gamma>1)$ is the substitution elasticity between the home and foreign baskets. The home bias in production ("input bias") is reflected in the parameter $\alpha, 0 \leq \alpha \leq 1 .{ }^{5}$ Home and foreign producers have an identical bias for the domestically produced intermediate good $\left(\alpha=\alpha^{*}\right)$. For $\alpha>.5$, there is a home bias in production. At given relative prices, home producers will demand relatively more home produced input goods than foreign producers. Of course, even if a home bias exists, home firms may demand more foreign inputs than home inputs in absolute terms if the relative price of the home produced input goods is sufficiently high. The reverse is the case (foreign bias) for $\alpha<.5$, and the ratio of home and foreign inputs will be the same in the home and foreign country if $\alpha=.5$.

The intermediate goods baskets are in turn CES aggregates across home and foreign brands.

$$
y_{t}^{h}=\left[\int_{0}^{1} y_{t}(i)^{\frac{\varphi-1}{\varphi}} d i\right]^{\frac{\varphi}{\varphi-1}} \quad \text { and } \quad y_{t}^{f}=\left[\int_{1}^{2} y_{t}^{*}(i)^{\frac{\varphi-1}{\varphi}} d i\right]^{\frac{\varphi}{\varphi-1}}
$$

Intermediate goods in the interval $[0,1]$ are produced in the home country, while goods in the interval $[1,2]$ are produced in the foreign country. For simplicity, we assume that the substitution elasticity $\varphi(\varphi>1)$ is identical in both economies. We further assume that the substitutability between goods from the same country is higher than between home and foreign goods, $\varphi \geq \gamma$ (Tille 2001).

Because of perfect competition, the prices of consumption goods equal firms' marginal cost so that the profit of final goods producers is zero in equilibrium. In sector I, final goods

\footnotetext{
${ }^{5}$ See Michaelis (2002) and Warnock (2003) for the analysis of a home bias in consumption in a new open economy macroeconomics model.
} 
producers' marginal costs are equal to the intermediate goods price index $\mathrm{P}_{t}^{\text {int er }}$, so that we have $\mathrm{P}_{\mathrm{t}}^{\mathrm{I}}=\mathrm{P}_{\mathrm{t}}^{\mathrm{int} e r}$. $\mathrm{P}_{\mathrm{t}}^{\mathrm{int} \text { er }}$ is given by:

$$
P_{t}^{\text {int er }}=\left[\alpha\left(p_{t}^{h}\right)^{1-\gamma}+(1-\alpha)\left(p_{t}^{f}\right)^{1-\gamma}\right]^{1-\gamma}
$$

$\mathrm{p}_{\mathrm{t}}^{\mathrm{h}}$ and $\mathrm{p}_{\mathrm{t}}^{\mathrm{f}}$ are price indexes (in home currency) that correspond to the intermediate goods bundles $\mathrm{y}_{\mathrm{t}}^{\mathrm{h}}$ and $\mathrm{y}_{\mathrm{t}}^{\mathrm{f}}$ and are given by:

$$
\mathrm{p}_{\mathrm{t}}^{\mathrm{h}}=\left[\int_{0}^{1}\left(\mathrm{p}_{\mathrm{t}}\right)^{1-\varphi} \mathrm{di}\right]^{\frac{1}{1-\varphi}} \quad \text { and } \quad \mathrm{p}_{\mathrm{t}}^{\mathrm{f}}=\left[\int_{1}^{2}\left(\mathrm{~S}_{\mathrm{t}} \mathrm{p}_{\mathrm{t}}^{*}\right)^{1-\varphi} \mathrm{di}\right]^{\frac{1}{1-\varphi}}
$$

where $p_{t}\left(p_{t}^{*}\right)$ denotes the price of a differentiated home (foreign) intermediate good in home (foreign) currency. $S_{t}$ is the nominal exchange rate defined as the price of one unit of foreign currency in terms of home currency. In sector II, the marginal production costs depend on the price of the domestic intermediate good basket used as the input. The price of a sector II consumption good is $\mathrm{P}_{\mathrm{t}}^{\mathrm{II}}=\mathrm{p}_{\mathrm{t}}^{\mathrm{h}}$.

Since there are no restriction to international trade, the law of one price holds for all differentiated intermediate goods, i.e. firms set their prices in the producer's currency. Profit maximization requires that the monopolistically competitive intermediate goods firms set their prices as a constant mark-up over their marginal costs, which equal the nominal wage, $\mathrm{p}_{\mathrm{t}}=\frac{\varphi}{\varphi-1} \mathrm{~W}_{\mathrm{t}}$.

The demand for home varieties of the intermediate goods is given in equation (13).

$$
\begin{aligned}
y_{t} & =t\left[\frac{p_{t}}{p_{t}^{h}}\right]^{-\varphi}\left\{\alpha\left[\frac{p_{t}^{h}}{P_{t}^{\text {int er }}}\right]^{-\gamma}\left[\frac{P_{t}^{\text {inter }}}{P_{t}}\right]^{-1} C_{t}+(1-\alpha)\left[\frac{p_{t}^{h}}{S_{t} P_{t}^{\text {int er }}}\right]^{-\gamma}\left[\frac{P_{t}^{\text {int er }}}{P_{t}^{*}}\right]^{-1} C_{t}^{*}\right\} \\
& +(1-t)\left[\frac{p_{t}}{p_{t}^{h}}\right]^{-\varphi}\left[\frac{p_{t}^{h}}{P_{t}}\right]^{-1} C_{t} .
\end{aligned}
$$

The demand for a differentiated home input stems from both home consumption goods sectors (reflected by the first term in brackets and the last term on the r.h.s.) and from the 
foreign consumption goods sector I (reflected by the second term in bracktes). Equation (13) implies that the parameter $\mathrm{t}$ can be interpreted as reflecting the degree of openness of both economies. Trade between both countries only exists for positive values of $t$. If $t$ is equal to zero both countries are closed economies. All consumption goods are produced in sector II so that there is no need to import goods from abroad.

\subsection{Government and the Current Account}

Government spending is assumed to be zero in each country so that the government budget constraint is $-\mathrm{P}_{\mathrm{t}} \mathrm{T}_{\mathrm{t}}=\mathrm{M}_{\mathrm{t}}-\mathrm{M}_{\mathrm{t}-1}$. The current account equation can now be derived by aggregating over the individual budget constraint (5) (thereby observing that $\pi_{t}^{\text {final }}=0$ in equilibrium due to perfect competition) and taking account of the government budget constraint given above.

$$
P_{t} C_{t}=y_{t} p_{t}+P_{t} B_{t-1}-\left(1+r_{t}\right) P_{t} B_{t}
$$

\section{The Log-linearized Model}

The model is analyzed in terms of percentage deviations around an initial symmetric steady state. The complete log-linear model as well as an explanation of its derivation is given in Appendix B. Three time periods are considered. The economy starts in the zero-steady state. In the middle period (the short run), a permanent monetary shock occurs. This period is characterized by nominal rigidities. Prices are predetermined in the short run and cannot be adjusted. In the next period, the economy moves to a new steady state, called the long run, in which all prices adjust instantaneously. To analyze the effects of monetary policy, we proceed by first looking at the long run and then turning to the short run. The policy experiment considered is a permanent increase in the relative home money supply.

\subsection{The Long Run (Steady State Changes)}

In the long run, firms adjust their prices according to the mark-up rule and households adjust their optimal labor supply according to equation (8). A bar over a variable indicates a long run change in a variable from the initial steady state to the new steady state (time subscripts are omitted). We look at cross-country differences defined as $\Delta \mathrm{X}=\mathrm{X}-\mathrm{X}^{*}$. Log-linearizing the model yields, for the new steady state: 


$$
\Delta \overline{\mathrm{P}}=\overline{\mathrm{S}}+(1-2 \mathrm{t}(1-\alpha)) \bar{\tau}
$$

$$
\begin{aligned}
& \Delta \overline{\mathrm{h}}=2 \mathrm{t}(1-\alpha) \bar{\tau}-\Delta \overline{\mathrm{C}} \\
& \Delta \overline{\mathrm{Y}}=\Delta \overline{\mathrm{C}}=\mathrm{t} \Delta \overline{\mathrm{C}}^{\mathrm{I}}+(1-\mathrm{t}) \Delta \overline{\mathrm{C}}^{\mathrm{II}} \\
& \Delta \overline{\mathrm{C}}-\Delta \overline{\mathrm{y}}=2 \mathrm{t}(1-\alpha) \bar{\tau}+2(1-\beta) \overline{\mathrm{B}} \\
& \Delta \overline{\mathrm{y}}=(1-2 \mathrm{t}(1-\alpha)) \Delta \overline{\mathrm{C}}-4 \mathrm{t}(1-\alpha)[(1-\mathrm{t})(1-\alpha)+\alpha \gamma] \bar{\tau} \\
& \Delta \overline{\mathrm{y}}=\Delta \overline{\mathrm{h}}
\end{aligned}
$$

$$
\Delta \overline{\mathrm{M}}=\Delta \overline{\mathrm{C}}+\overline{\mathrm{S}}+(1-2 \mathrm{t}(1-\alpha)) \bar{\tau}
$$

Linearizing the CPI equation (3) and its foreign counterpart and considering the definition of the home country's terms of trade, $\bar{\tau}$, yields equation (15). ${ }^{6}$ The size of sector II in combination with the extent of the input bias causes long run deviations from purchasing power parity (PPP). In contrast to the paper by Warnock (2003), PPP does not necessarily hold in our model even if no bias exists $(\alpha=1 / 2)$. PPP only holds in the new steady state, if $\mathrm{t}(1-\alpha)=1 / 2 .^{7}$ Then, the long run real exchange rate defined as $\overline{\mathrm{Q}}=\Delta \overline{\mathrm{P}}-\overline{\mathrm{S}}$ is constant.

Equation (16) gives the optimal labour supply differential (log-linearized version of equation (8) and its foreign counterpart). An increase in the consumption differential ceteris paribus leads to a relatively stronger substitution of leisure for labor in the home country and thus to a fall in the labour supply differential. Relative labor supply is further positively affected by the long run change in the terms of trade as long as there is no extreme home input bias $(\alpha<1)$ and inputs from abroad are needed in the production of domestic consumption goods $(\mathrm{t}>0)$. In addition, log-linearizing the intermediate goods firms' production function shows that the labour differential moves one to one with cross-country output (see equation (20)).

\footnotetext{
${ }^{6} \tau_{t}$ is defined as $\tau_{t}=p_{t} /\left(S_{t} p_{t}^{*}\right)$ so that an increase in $\tau_{t}$ represents an improvement in the terms of trade.

${ }^{7}$ For $t=1$ our model replicates the result of Warnock (2003) where long run deviations from PPP are caused by a home bias only.
} 
The consumption differential equals the relative production of consumption goods (equation 17)). The share of the consumption goods from both sectors in overall consumption is determined by the parameter $\mathrm{t}$, which, as pointed out above, reflects the economies' openness since it determines the relative size of the consumption goods sectors. The log-linearized version of the long run current account equation for the home and the foreign country (equation (14) and its foreign counterpart) leads to the conclusion that an improvement in the long run terms of trade and an increase in foreign long run indebtedness to the home country induces an increase in relative consumption and/or a decline in relative labor supply (see equation (18)). Intuitively, the effect of terms of trade changes increases if $t$ increases (i.e. the openness of the economies increases) and the input bias declines so that the countries' interdependence increases.

Equation (19) is obtained through linearizing the equilibrium conditions for home and foreign intermediate goods (equation (13) and its foreign counterpart). The relative demand for home intermediate goods grows with relative consumption as long as $t(1-\alpha)<1 / 2$. This condition is more likely to be fulfilled if domestic inputs are predominantly needed for the production of domestic consumption goods (i.e. the home input bias is quite pronounced and $t$ is quite small). The long run terms of trade change is negatively related to the relative intermediate goods output. An improvement (i.e. increase) in Home's terms of trade causes an expenditure switching effect in favor of foreign goods. The strength of this effect increases in the substitutability of home and foreign goods $(\gamma)$, the economies' openness (provided there is no large foreign input bias) and decreases in the extent of the home input bias.

Changes in the long run cross-country money demand depend on relative consumption changes and the long run CPI differential (equation (21)). In the new steady state, the real interest rate does not change, $\overline{\mathrm{r}}=0$.

\subsection{The Short Run}

In the short run, the intermediate goods prices are predetermined. They can only be adjusted in the new steady state. Hence, the output of intermediate goods in the short run is not governed by the labor-leisure trade-off in equation (8). Market demand is met at the pre-set price, i.e. output of intermediate goods is determined by equation (13). Monopolistic 
competition provides a theoretical basis for output to accommodate demand because prices are set above marginal cost. ${ }^{8}$ In the short run, the system is shocked by an unanticipated permanent increase in the relative money supply of the home country, $\hat{\mathrm{M}}-\hat{\mathrm{M}}^{*}=\overline{\mathrm{M}}-\overline{\mathrm{M}}^{*}>0$. Short run deviations from the initial steady state are denoted by hats over variables.

Using the linearized version of the relative money demand equation (for the short and the long run) and the short run cross-country optimal consumption path (see below), it can be shown that the exchange rate immediately adjusts to its long run equilibrium value after a monetary shock $(\hat{\mathrm{S}}=\overline{\mathrm{S}}){ }^{9}$ Since the prices for intermediate goods cannot change in the short run $\left(\hat{p}=\hat{p}^{*}=0\right)$, changes in the short run CPI can only be caused by (permanent) exchange rate changes, $\hat{\mathrm{P}}=(1-\alpha) \mathrm{t} \overline{\mathrm{S}}$.

Even if consumption goods are nontradeables, the CPI is not insulated from exchange rate changes if tradeable inputs are required in the production process. The strength of the CPI response, i.e., sensitivity of the CPI to nominal exchange rate movements, is determined by the input bias and by the relative size of the consumption goods sectors. Intuitively, the greater is the input bias, the weaker is the effect of exchange rate changes on the CPI. If there is an extreme input bias, $\alpha=1$, the CPI does not react at all to exchange rate fluctuations. Similarly, if $\mathrm{t}$ converges to zero, so that all goods consumed stem from sector II, which completely relies on domestically produced inputs, the impact of exchange rate changes on the CPI also vanishes independently of the input bias. Both the extent of the home bias and the existence of sector II lead to a violation of purchasing power parity in the short run. Unlike Warnock's (2003) paper, the short run real exchange rate, $\hat{\mathrm{Q}}=\Delta \hat{\mathrm{P}}-\overline{\mathrm{S}}=(2(1-\alpha) \mathrm{t}-1) \overline{\mathrm{S}}$, may change even if no bias exists and it may be a constant even if a bias exists. The relative size of the consumption goods sectors has to be adjusted suitably.

\footnotetext{
${ }^{8}$ We asssume that the participation constraint is not violated. I.e., we only consider small shocks that do not push marginal costs above prices so that it is never optimal for firms to stop producing. See Corsetti and Pesenti (2001a) for a detailed analysis and interpretation of the participation constraint.

${ }^{9}$ In the more general case that the consumption elasticity of money demand is below unity, an overshooting of the exchange rate in response to a monetary shock is possible (see, e.g., Betts and Devereux 2000).
} 
The change in the intermediate good price index in the short run is $\hat{\mathrm{P}}^{\mathrm{int} e r}=(1-\alpha) \overline{\mathrm{S}}$. Thus, the response to exchange rate changes is higher on the intermediate goods than on the final goods level, which is consistent with empirical evidence (see the Introduction).

The remainder of the log-linearized model in the short run in terms of cross-country differences is

$$
\begin{aligned}
& \Delta \hat{\mathrm{C}}=\Delta \overline{\mathrm{C}}+(\hat{\mathrm{S}}-\Delta \hat{\mathrm{P}})-(\overline{\mathrm{S}}-\Delta \overline{\mathrm{P}}) \\
& \Delta \hat{\mathrm{Y}}=\Delta \hat{\mathrm{C}}=\mathrm{t} \Delta \hat{\mathrm{C}}^{\mathrm{I}}+(1-\mathrm{t}) \Delta \hat{\mathrm{C}}^{\mathrm{II}} \\
& \Delta \hat{\mathrm{C}}-\Delta \hat{\mathrm{y}}=-2 \mathrm{t}(1-\alpha) \overline{\mathrm{S}}-2 \beta \overline{\mathrm{B}} \\
& \Delta \hat{\mathrm{y}}=(1-2 \mathrm{t}(1-\alpha)) \Delta \hat{\mathrm{C}}+4 \mathrm{t}(1-\alpha)[(1-\mathrm{t})(1-\alpha)+\alpha \gamma] \overline{\mathrm{S}} \\
& \Delta \hat{\mathrm{y}}=\Delta \hat{\mathrm{h}} \\
& \Delta \overline{\mathrm{M}}=\Delta \hat{\mathrm{C}}+2 \mathrm{t}(1-\alpha) \overline{\mathrm{S}}
\end{aligned}
$$

Equation (22) is the log-linearized version of the relative consumption paths (equation (6) and its foreign counterpart). If the real exchange rate moves immediately to its new steady state level, the consumption differential also reaches its long run value immediately after a shock. This is only the case if PPP holds (i.e. $\mathrm{t}(1-\alpha)=1 / 2$ as derived in the previous subection) so that changes in agents' intertemporal allocation of consumption are identical across countries. Log-linearizing the consumption market equilibrium conditions shows that the short run consumption differential equals the relative production of consumption goods in the short run (equation (23).

The relative short run movement of the current account is given in equation (24). A depreciation of the exchange rate in response to the asymmetric monetary shock ceteris paribus leads to a current account surplus for the home country. A larger home current account surplus of course means that Home accumulates more net claims on the foreign country ( $\overline{\mathrm{B}}$ increases) for a given change in the exchange rate.

Equation (25) gives the linearized version of the equilibrium condition for home intermediate goods in the short run. The short run change in cross-country output positively depends on the 
change in the short run consumption differential and on the expenditure switching effect generated by the change in the exchange rate (the short run terms of trade deteriorate and are given by $\hat{\tau}=-\overline{\mathrm{S}}) .{ }^{10}$ Of course, the substitution effect of exchange rate changes increases in the substitutability between home and foreign goods $(\gamma)$. If PPP holds, the short run output differential is exclusively driven by the input substitution of intermediate goods firms (second term on the r.h.s. of equation (25)). If, however, intermediate goods from abroad are not needed in home and foreign production processes $(\alpha=1$ and/or $t=0)$, the movement of relative home output is only governed by the change in the short run consumption differential.

Equation (26) states that an one percent increase in labor input results in an equal increase in intermediate goods output in the short run. Finally, equation (27) shows that in the short run the money supply differential depends on the short run consumption differential and on exchange rate movements. This linearized version of the money demand equations also sheds some light on the model's exchange rate dynamics if it is reformulated.

$$
\overline{\mathrm{S}}=\frac{\Delta \overline{\mathrm{M}}-\Delta \overline{\mathrm{C}}}{2 \mathrm{t}(1-\alpha)} .
$$

The exchange rate only reacts to a monetary shock if at least some firms operate in sector I $(\mathrm{t}>0)$ and the home bias for input goods is not extreme $(\alpha<1)$. If one of these conditions is not met, relative money supply changes only lead to equal changes in the short run consumption differential. If PPP holds, the exchange rate moves one to one with the increase in the money supply differential. For other values of $\alpha$ and t, however, the volatility of the exchange rate may be higher or lower than the volatility of the money supply differential. The more dependent the home economy is on the rest of the world ( $\mathrm{t}$ is relatively high and $\alpha$ small), the weaker is the reaction of the exchange rate to relative money supply changes. The higher is the home input bias and the less open the economy ( $\mathrm{t}$ is small) is, the more the exchange rate effect of monetary policy is exacerbated.

\footnotetext{
${ }^{10}$ The movement of the short run terms of trade indicates that our set-up allows for a reconciliation of the works of Betts and Devereux (1996, 2000) and Obstfeld and Rogoff (2000). In Betts and Devereux' work, the limited degree of pass-through, based on the local currency pricing paradigm, leads to an improvement in the short run terms of trade when a country's currency depreciates. This implication is not matched by the data as argued by Obtsfeld and Rogoff who therefore argue in favor of modelling full pass-through. In this paper, however, a limited pass-through is associated with a deterioration in the expanding country's short run terms of trade.
} 


\section{$4 \quad$ Closed Form Solutions}

\subsection{Long Run Solution}

Closed form solutions for long run cross-country differences and individual variables are:

$$
\Delta \overline{\mathrm{y}}=-\frac{2 \mathrm{t} \alpha(1-\alpha)(1-\beta)(\gamma-1)}{\psi} \Delta \overline{\mathrm{M}}
$$$$
\Delta \overline{\mathrm{C}}=\Delta \overline{\mathrm{Y}}=\frac{2 \mathrm{t} \alpha(1-\alpha)(1-\beta)(\gamma-1)[1+2((1-\mathrm{t})(1-\alpha)+\alpha \gamma)]}{(2 \alpha(\gamma-1)+1) \psi} \Delta \overline{\mathrm{M}}
$$

$$
\overline{\mathrm{y}}=-\frac{\mathrm{t} \alpha(1-\alpha)(1-\beta)(\gamma-1)}{\psi} \Delta \overline{\mathrm{M}}
$$

$$
\overline{\mathrm{C}}=\overline{\mathrm{Y}}=\frac{\mathrm{t} \alpha(1-\alpha)(1-\beta)(\gamma-1)[1+2((1-\mathrm{t})(1-\alpha)+\alpha \gamma)]}{(2 \alpha(\gamma-1)+1) \psi} \Delta \overline{\mathrm{M}}
$$

$$
\bar{\tau}=\frac{2 \alpha(1-\mathrm{t}(1-\alpha))(1-\beta)(\gamma-1)}{(2 \alpha(\gamma-1)+1) \psi} \Delta \overline{\mathrm{M}}
$$

$$
\overline{\mathrm{B}}=\frac{2 \mathrm{t} \alpha(1-\alpha)(\gamma-1)}{\psi} \Delta \overline{\mathrm{M}}
$$

where $\psi=1+2 \operatorname{ta}(1-\alpha)(1-\beta)(\gamma-1)$. The key variable for the long run effects of monetary policy is the change in Home's net foreign asset position (equation (34), see also Appendix C). ${ }^{11}$ Home accumulates net claims against Foreign in response to the monetary shock, giving rise to a permanent redistribution of wealth from Foreign to Home. In the long run, the relative output of intermediate goods (and labor input) turns negative while the consumption differential is positive (equations (29) and (30)). Households in Home, as the net creditor country, decrease their labor supply and enjoy an increase in leisure (equation (31)). The home terms of trade improve in response to the monetary expansion (equation ((33)) and home households' increased consumption spending is financed through the wealth transfer from abroad (equation (32)). Households in Foreign as the net debtor country, on the other

\footnotetext{
${ }^{11}$ The change in the net foreign asset position can only be solved for with the help of the short run solutions presented in the next subsection. The permanent change in the net foreign position is caused by current account imbalances in the short run.
} 
hand, have to work more and reduce their consumption spending to be able to service their debt (see, e.g., Obstfeld and Rogoff 1995, 1996 for a more thorough exposition of the wealth effects of monetary policy).

These long run effects of monetary policy crucially depend on the model's key parameters, $\alpha$ and $t$. If $t=0$, Home's net foreign position does not change in the long run so that monetary policy does not lead to an international transfer of wealth. In this case, neither country needs inputs from abroad. The interdependence of both countries on one another vanishes and Home and Foreign are closed economies. $\overline{\mathrm{B}}$ increases in $\mathrm{t}$ and ceteris paribus reaches its maximum for $t=1$. Analogously, the wealth effects of monetary policy disappear for an extreme home or foreign input bias $(\alpha=0$ or $\alpha=1)$. An increase in the home input bias parameter, $\alpha$, enhances Home's net foreign position as long as a foreign input bias prevails $(\alpha<.5)$ and reduces Home's net foreign position if a home input bias exists $(\alpha>.5) . \overline{\mathrm{B}}$ gets largest and hence the permanent effects of monetary policy are strongest if no input bias exists $(\alpha=.5)$. If there is a strong bias in favor of home or foreign inputs, the input substitution between home and foreign intermediate goods brought about by a change in relative prices is rather weak. Consequently, the current account imbalances in the short run which give rise to the redistribution of wealth in the long run, are considerably weak. Firms are reluctant to switch between home and foreign goods since they (strongly) favor one type of good. If, however, there is no input bias, the movement in relative prices matters more. Now, firms have a strong incentive to substitute between foreign and home goods, giving rise to large current account imbalances in the short run and, hence, large changes in countries' net foreign positions.

Concerning individual and cross-country variables, money is not neutral even if prices are fully flexible, but monetary policy has no global real effects. Global consumption and intermediate good production is zero in the new steady state, $\overline{\mathrm{C}}^{\mathrm{w}}=0$ and $\overline{\mathrm{y}}^{\mathrm{w}}=0$, where the superscript " $w$ " denotes a population-weighted sum of home and foreign variables $\left(\mathrm{X}^{\mathrm{w}}=.5\left(\mathrm{X}+\mathrm{X}^{*}\right)\right.$. The neutrality of money in the presence of price flexibility thus holds if worldwide (global) aggregates are considered.

\subsection{Short Run}

Relative short run changes in home country variables and in home individual variables in closed form are given by: 


$$
\Delta \hat{\mathrm{y}}=\frac{1+2 \operatorname{t\alpha }(1-\alpha)(1+\beta)(\gamma-1)}{\psi} \Delta \overline{\mathrm{M}}
$$

$$
\Delta \hat{\mathrm{C}}=\Delta \hat{\mathrm{Y}}=\frac{[1-2 \mathrm{t}+2 \alpha(\gamma-(1-\mathrm{t}))] \psi-4 \mathrm{t} \beta \alpha(1-\alpha)(\gamma-1)}{(2 \alpha(\gamma-1)+1) \psi} \Delta \overline{\mathrm{M}}
$$

$$
\hat{\mathrm{y}}=\overline{\mathrm{M}}^{\mathrm{w}}+\frac{1}{2} \frac{1+2 \mathrm{t} \alpha(1-\alpha)(1+\beta)(\gamma-1)}{\psi} \Delta \overline{\mathrm{M}}
$$

$$
\hat{\mathrm{C}}=\hat{\mathrm{Y}}=\overline{\mathrm{M}}^{\mathrm{w}}+\frac{1}{2} \frac{[1-2 \mathrm{t}+2 \alpha(\gamma-(1-\mathrm{t}))] \psi-4 \mathrm{t} \beta \alpha(1-\alpha)(\gamma-1)}{(2 \alpha(\gamma-1)+1) \psi} \Delta \overline{\mathrm{M}}
$$

$$
\hat{\mathrm{r}}=-\frac{1}{1-\beta}\left(\overline{\mathrm{M}}^{\mathrm{w}}+\frac{1-2 \mathrm{t}(1-\alpha)}{2 \psi} \Delta \overline{\mathrm{M}}\right)
$$

$$
\overline{\mathrm{S}}=\frac{1+2 \alpha(\gamma-1)[\mathrm{t}(1-\beta)(1-\alpha)+\beta]}{(2 \alpha(\gamma-1)+1) \psi} \Delta \overline{\mathrm{M}}
$$

Equations (35) and (37) show that the output differential and home individual output move in exactly the opposite direction in the short run as compared to the long run. Home relative and individual output unambiguously increase in response to an increase in the relative home money supply. For the same reason as discussed above, the change in cross-country and individual output reaches its maximum if $\mathrm{t}=1$ and $\alpha=.5$. Generally, home relative output increases more than one to one with the expansion of Home's relative money supply as long as the adjustment in relative prices produces an input substitution effect (i.e. $t>0$ and $0<\alpha<1)$. Otherwise, the (relative) demand for inputs is not affected by exchange rate changes and the change in (relative) short run output is fully caused by the income effect of the relative monetary expansion. Equation (37), giving the short run change in home output, clearly shows the two distinct factors that impinge upon individual output movement. The expenditure increasing effect of a change in world demand is represented by $\overline{\mathrm{M}}^{\mathrm{w}}$ and the expenditure-switching effect of exchange rate fluctuations is reflected in the second term of the r.h.s of equation (37). Equation (40) shows that the exchange rate depreciates permanently in reponse to the (permanent) relative expansion of the home money supply. Generally, the switch away from foreign towards home inputs is stronger the higher is the elasticity of substitution, $\gamma$. 
The movement of home and foreign output in response to a monetary shock is further affected by the exchange rate driven change in marginal costs. Since the law of one price holds, exchange rate changes are fully passed-through to the intermediate goods prices, thus depressing output in the home country and increasing output in the foreign country for an expansion in the relative home money supply. Of course, the strength of this effect crucially depends on the input bias parameter $\alpha$. Although the pass-through to individual goods prices is complete, marginal costs may be only weakly affected by exchange rate changes or may even be isolated from them if a considerable home bias $(\alpha>.5)$ or even an extreme input bias $(\alpha=1)$ prevails.

The short run consumption differential (36) and individual short run consumption (38) are subject to several effects. The increase in cross-country output and in home ouput implies an increase in home (relative) income. Part of this income increase is consumed, thus increasing home consumption relative to foreign consumption in the short run, and the remaining part is saved for consumption smoothing purposes (as discussed above, for $\alpha=0, \alpha=1$ or $\mathrm{t}=0$, the consumption path is unaffected by monetary policy adjustments, see equation (34)).

Household's optimal consumption path is affected by changes in the real interest rate. Home households' incentive to save more (and consequently, to consume less in the short run) positively depends on the real interest rate given in equation (39). If PPP holds, a monetary expansion anywhere in the world leads to an interest rate decrease and thus reduces the opportunity cost of short run consumption. If PPP is violated $(t(1-\alpha) \neq 1 / 2)$, the real interest rate is further affected by the difference between the long run and the short run real exchange rate reflected in the second term in brackets. This second effect has an ambiguous sign rendering the interest rate response ambiguous, too. If the real exchange rate overshoots in the short run, it will appreciate from the short to the long run implying an increase in the real interest rate that Foreign has to pay for its debt in terms of foreign goods. ${ }^{12}$ Thus, foreign households are given an incentive to borrow less from home households so that Home's short run consumption ceteris paribus increases (the reverse argument applies to the undershooting case).

${ }^{12}$ The real exchange overshoots in the short run if $t(1-\alpha)<1 / 2$ and undershoots if $t(1-\alpha)>1 / 2$. 
Moreover, due to the exchange rate depreciation Home is faced with a loss in its purchasing power while Foreign enjoys an increase in its purchasing power. This effect tends to suppress home consumption through the money market while foreign consumption is stimulated. The strength of this effect depends on how responsive the CPI is to exchange rate fluctuations which is determined by the relative size of the consumption goods sectors and the input bias. If this responsiveness is low or even zero, individual consumption and the consumption differential are (nearly) insulated from this real balances adjustment (if $t=0$ or $\alpha=1$ we

simply have $\hat{\mathrm{C}}=\hat{\mathrm{M}}$ ). The change in home and foreign purchasing power reaches its maximum for $\mathrm{t}=1$ and $\alpha=0$. In this case, the loss in purchasing power is so severe that the change in the consumption differential is unambiguously negative $(\Delta \hat{\mathrm{C}}=-\Delta \hat{\mathrm{M}})$ and home consumption entirely depends on foreign monetary policy $\left(\hat{\mathrm{C}}=\hat{\mathrm{M}}^{*}\right)$. The effect of a change in the home money supply on home consumption is perfectly offset by the associated increase in the CPI. For intermediate values of the model's key parameters $t$ and $\alpha$, the movement in the consumption differential is theoretically not unambiguous. Globally, however, consumption and output (and thus effort) unambiguously increase in the short run, $\hat{\mathrm{C}}^{\mathrm{w}}=\hat{\mathrm{y}}^{\mathrm{w}}=\hat{\mathrm{M}}^{\mathrm{w}}$.

\section{Welfare Effects and the International Transmission of Monetary Policy}

Equipped with the long run and the short run solutions we can now turn to the welfare analysis of monetary policy. Besides the welfare effect in the home country, the international transmission of monetary policy is of particular interest. On this basis, it can be assessed whether countries have an incentive to react to monetary adjustments in a neighboring country. Therefore, in this section equations for the foreign country are (also) presented. Following Obstfeld and Rogoff $(1995,1996)$ and others, we concentrate on the "real" part of households' utility function and assume that the effect of real balances on utility is small enough to be neglected. Hence:

$$
\mathrm{dU}_{\mathrm{t}}=\hat{\mathrm{C}}-\frac{\varphi-1}{\varphi} \hat{\mathrm{y}}+\frac{\beta}{1-\beta}\left(\overline{\mathrm{C}}-\frac{\varphi-1}{\varphi} \overline{\mathrm{y}}\right)
$$

The cross-country welfare change as well as home and foreign individual welfare changes are given by 


$$
\begin{aligned}
& \mathrm{d}\left(\mathrm{U}_{\mathrm{t}}-\mathrm{U}_{\mathrm{t}}^{*}\right)=\frac{(1+2 \mathrm{t} \alpha(1-\alpha)(\gamma-1))[(2 \alpha(\gamma-1)+1) / \varphi-2 \mathrm{t}(1-\alpha)]}{(2 \alpha(\gamma-1)+1) \psi} \Delta \overline{\mathrm{M}} . \\
& \mathrm{dU}_{\mathrm{t}}=\frac{1}{\varphi} \overline{\mathrm{M}}^{\mathrm{w}}+\frac{(1+2 \mathrm{t} \alpha(1-\alpha)(\gamma-1))[(2 \alpha(\gamma-1)+1) / \varphi-2 \mathrm{t}(1-\alpha)]}{2(2 \alpha(\gamma-1)+1) \psi} \Delta \overline{\mathrm{M}} . \\
& \mathrm{dU}_{\mathrm{t}}^{*}=\frac{1}{\varphi} \overline{\mathrm{M}}^{\mathrm{w}}-\frac{(1+2 \mathrm{t} \alpha(1-\alpha)(\gamma-1))[(2 \alpha(\gamma-1)+1) / \varphi-2 \mathrm{t}(1-\alpha)]}{2(2 \alpha(\gamma-1)+1) \psi} \Delta \overline{\mathrm{M}} .
\end{aligned}
$$

Equations (43) - (45) show that the welfare consequences of monetary policy changes can be split up into two effects. First, a money supply change affects all countries equally through the expenditure increasing effect represented by the first terms in equations (44) and (45). Of course, this effect cancels out if relative welfare is considered (equation (43)). Second, countries are differently affected by the expenditure switching effect captured through the second terms in equations (44) and (45). Globally, the welfare gain of an expansionary monetary policy anywhere in the world only depends on its expenditure increasing effect, $\mathrm{dV}_{\mathrm{t}}^{\mathrm{w}}=(1 / \varphi) \overline{\mathrm{M}}^{\mathrm{w}}$.

For certain parameter values, the model is able to replicate the welfare results of other studies. For the special case, $\alpha=.5, \mathrm{t}=1$ and $\varphi=\gamma$, e.g., we have Obstfeld and Rogoff's (1995) result that welfare in each country only depends on the global money supply $\left(\overline{\mathrm{M}}^{\mathrm{w}}\right)$ and monetary policy thus has prosper-thy-neighbor and prosper-thyself effects. Welfare in all countries would be equally affected by a monetary policy change anywhere in the world so that the cross-country difference of welfare changes is zero for these parameter settings.

To better demonstrate the parameter dependence of the welfare results, a numerical example is presented in the following. Parameter values apart from $\alpha$ and $t$ are taken from the literature $(\beta=0.94, \varphi=6){ }^{13}$ Two scenarios are considered. In the first, the cross-country substitutability is comparatively low $(\gamma=1.5),{ }^{14}$ in the second the substitutability between home and foreign inputs is assumed to be relatively high $(\gamma=5.5)$. Figures 1 and 2 graphically present equations (44) and (45) for varying degrees of openness (t) and of the

\footnotetext{
${ }^{13}$ See the numerical examples of, e.g., Betts and Devereux (1996, 2000), Chari, Kehoe and McGrattan (2002) and Warnock (2003).

${ }^{14}$ For consumption goods, the cross-country substitutability is estimated to lie between one and two (Backus, Kehoe and Kydland 1994).
} 
input bias $(\alpha)$. We assume a $1 \%$ permanent increase in the home money supply while the foreign money supply is held constant.

A home monetary expansion may seriously deteriorate home welfare especially if the degree of substitutability between home and foreign inputs is low (see figures 1a and 1b). The beggar-thyself effect of monetary policy is largest if the mutual dependence of the economies on each other is quite high (i.e. if $\alpha$ is close to zero and $t$ is close to one). The long run welfare is still positive for these parameter values (albeit very small in magnitude since the redistribution of wealth is small for $\alpha$ being close to one or zero). Home short run welfare, however, is negative unless the impact of exchange rate changes on the CPI and the intermediate goods price index is considerably restricted through a large home input bias (large value of $\alpha$ ) and/or large relative size of the consumption goods sector that only needs domestic inputs (small value of $\mathrm{t}$ ). An increase in interdependence is associated with a stronger response of the CPI and the intermediate goods price to exchange rate movements. For $t=1$ and simultaneously $\alpha=0$, both price indexes move one to one with the exchange rate. The resulting loss in consumers' purchasing power prevents home real consumption from increasing in response to a home monetary expansion. Since the labor effort is still quite high in this situation (foreign firms demand domestic inputs), the short run and the overall welfare effect is negative.

A monetary expansion tends to benefit the expanding country if there is a (strong) home input bias and/or $\mathrm{t}$ is rather small. For these combinations of the model's key parameters, the links between both economies are rather weak and the welfare results therefore resemble those of closed economies (for $\mathrm{t}=0$ or $\alpha=1$, the economies are closed). Hence, a large home bias can "offset" a large degree of openness (reflected in a large t) and vice versa. These prosperthyself effects are small in magnitude compared to the beggar-thyself effects discussed above. The degree of substitutability between home and foreign goods $\gamma$ does not change the results generally. The higher is $\gamma$, the larger are the positive long run welfare results of monetary policy since the redistribution of wealth in the long run from the foreign to the home country increases in $\gamma$ (see equation (34)). Hence, monetary policy is beneficial for the home country for a wider range of parameter values. The conclusion can be drawn that an expansionary monetary policy seems to be a policy option only for relatively closed economies with only minor monopolistic distortions. 
Foreign welfare is improved for almost all parameter values by a home monetary expansion (see figures $2 \mathrm{a}$ and $\mathrm{b}$ ). The more dependent the home country is on foreign inputs (the smaller $\alpha$ and, at the same time, the larger $t$ ) the more the foreign country profits from the home expansion. In the short run, foreign consumption increases quite strongly for this parameter combination while foreign effort, however, is hardly affected. Since, moreover, exchange rate changes generate only weak switching effects if there is a large input bias in either direction, the negative welfare consequences in the long run tend to be small. Thus, overall foreign welfare increases in the degree of openness, $t$, and decreases in the input bias parameter, $\alpha$. Of course, if the home country does not depend on inputs from abroad at all ( $\mathrm{t}=0$ or $\alpha=1)$, foreign welfare does not react to home monetary adjustments.

For the welfare effects on the foreign country, $\gamma$ is of key importance. Monetary policy only has beggar-thy-neighbor effects for a small range of parameter values if the substitutability between home and foreign goods is sufficiently high as in figure $2 \mathrm{~b}$. The negative long run effects of monetary policy on the foreign country's welfare strongly increase in $\gamma$, since the foreign current account deficit increases in $\gamma$ (see equation (34) again). ${ }^{15}$ Although the short run welfare (which is unambiguously positive, independent of $\gamma$ ) increases in the crosscountry substitutability as well, the long run welfare effect dominates for large values of both $\alpha$ and $\mathrm{t}$ (for this parameter combination both the short run decline in foreign effort and the increase in foreign consumption is close to nil). Hence, foreign overall welfare may be adversely affected for these parameter values.

With respect to the substitutability of home and foreign intermediate goods $(\gamma)$, one can conclude that the weaker the monopolistic distortions are (i.e. the larger is $\gamma$ ), the more likely it is that the conventional wisdom of beggar-thy-neighbor and prosper-thyself effects of an expansionary monetary policy holds. ${ }^{16}$

${ }^{15}$ If $\gamma=1$ as in Corsetti and Pesenti (2001a), monetary policy has no long run effects at all since no current account imbalances arise and hence, no wealth transfer occurs in the long run. Monetary policy would now be unambiguously prosper-thy-neighbor in our model.

${ }^{16}$ Michaelis (2002) derives a similar result. 


\section{Conclusion}

Using a fully dynamic new open economy macroeconomics model, this paper examines how the existence of intermediate goods and two consumption good sectors that to different degrees rely on inputs from abroad affect the transmission of monetary policy changes. We further assume that an equal input bias in the production of final consumption goods exists in the world. This set-up allows us to capture the logic of some of the most prominent extensions of the Obstfeld and Rogoff (1995) model and to study their interaction.

Key for the model's results are the openness of the economies, the degree of interdependence and the competitiveness of markets. A monetary expansion is more likely to have a beneficial effect for the expanding country, the less open the expanding country is. Hence, monetary policy has prosper-thyself effects if inputs from abroad only have a small weight in the production of consumption goods (either through a strong input bias or a vast share of consumption goods in the consumption basket that are produced without foreign intermediate goods), making the country by and large independent of the rest of the world. Moreover, the likelihood of prosper-thyself effects increases with the competitiveness of markets. One is therefore led to the conclusion that a monetary expansions adversely affects the expanding country if it is strongly linked to its trading partners and/or the monopolistic distortions are quite strong. Concerning the welfare effects in the rest of the world, one can conclude that other economies are very rarely adversely affected by a monetary expansion in the home country. For a wide range of parameter values they even benefit. Beggar-thy-neighbor effects only occur for relatively competitive markets.

There a many topics for further research based on the insights gained from our model. In particular in a stochastic version of the model several interesting issues can be addressed. Optimal monetary policy in response to shocks and the model's implications for the international dimension of monetary policy could be explored as well as the model's implications for the international coordination of monetary policy (along the lines of, e.g., Benigno 2001, Corsetti and Pesenti 2001b, Obstfeld and Rogoff 2002 and Sutherland 2002). 


\section{Figures}

Figure 1a: The Welfare Effects of Monetary Policy on Home for $\gamma=1.5$

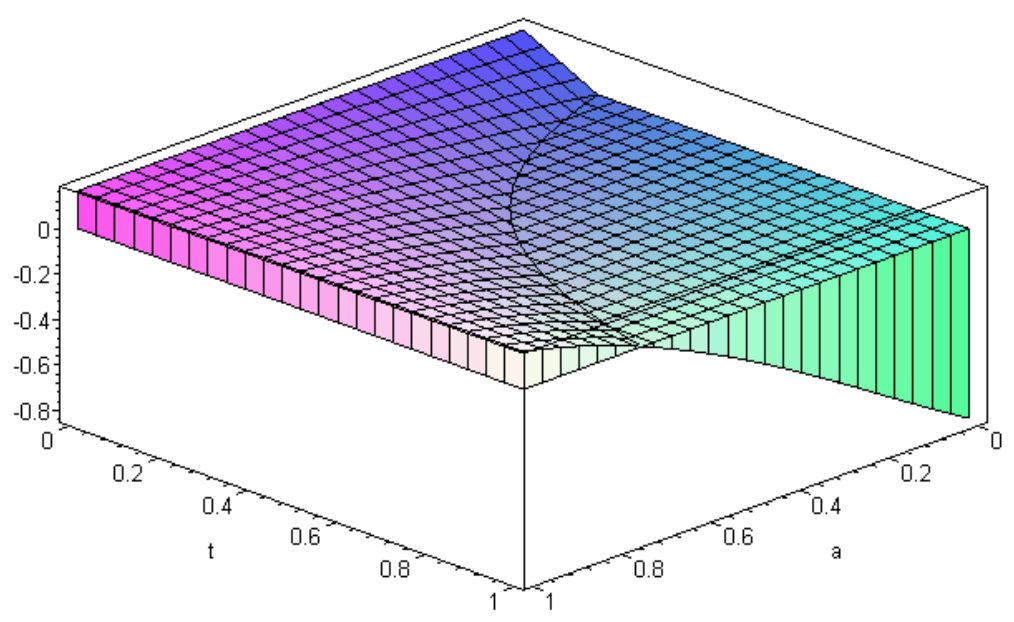

Figure 1b: The Welfare Effects of Monetary Policy on Home for $\gamma=5.5$

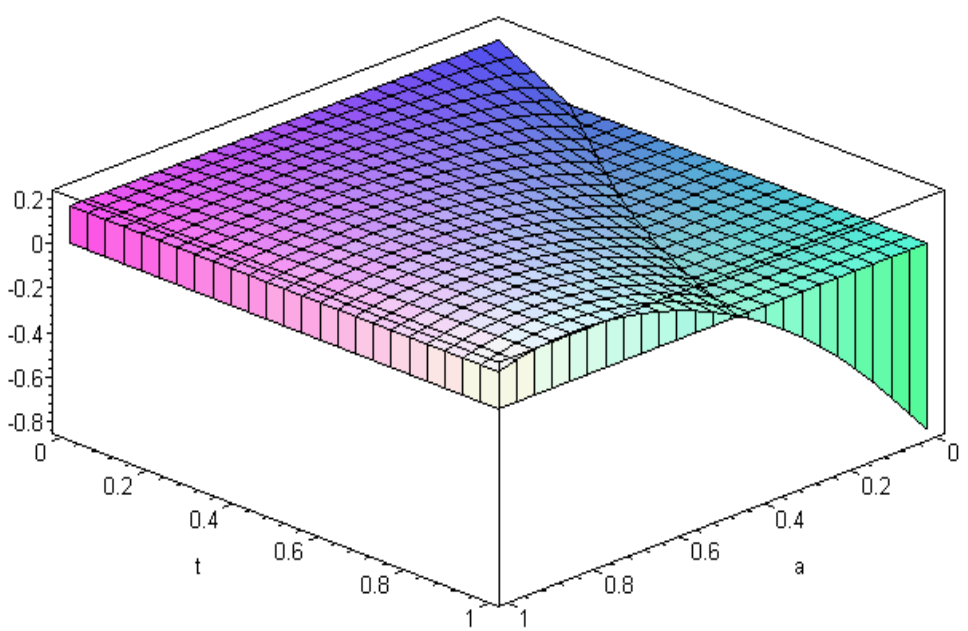


Figure 2a: The Welfare Effects of Monetary Policy on Foreign for $\gamma=1.5$

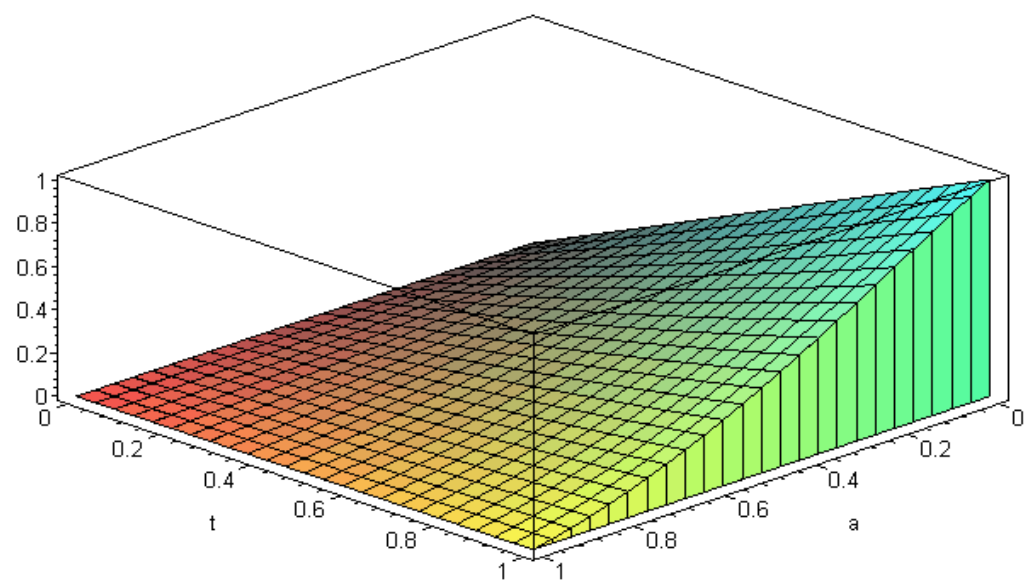

Figure 2b: The Welfare Effects of Monetary Policy on Foreign for $\gamma=5.5$

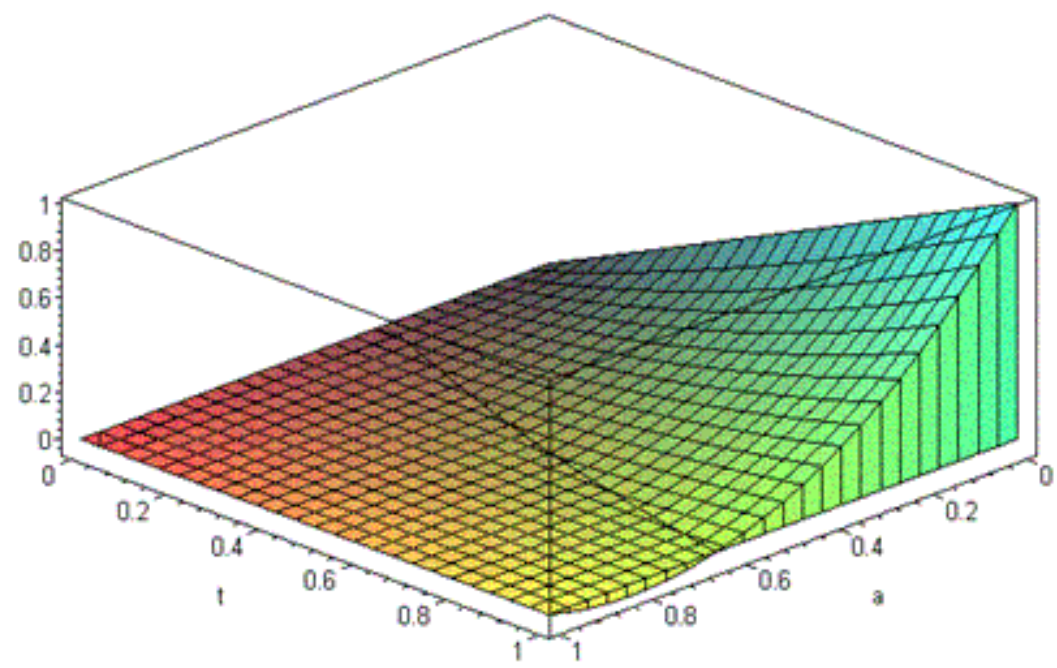




\section{Appendix}

A Table 1: Equations for the foreign country

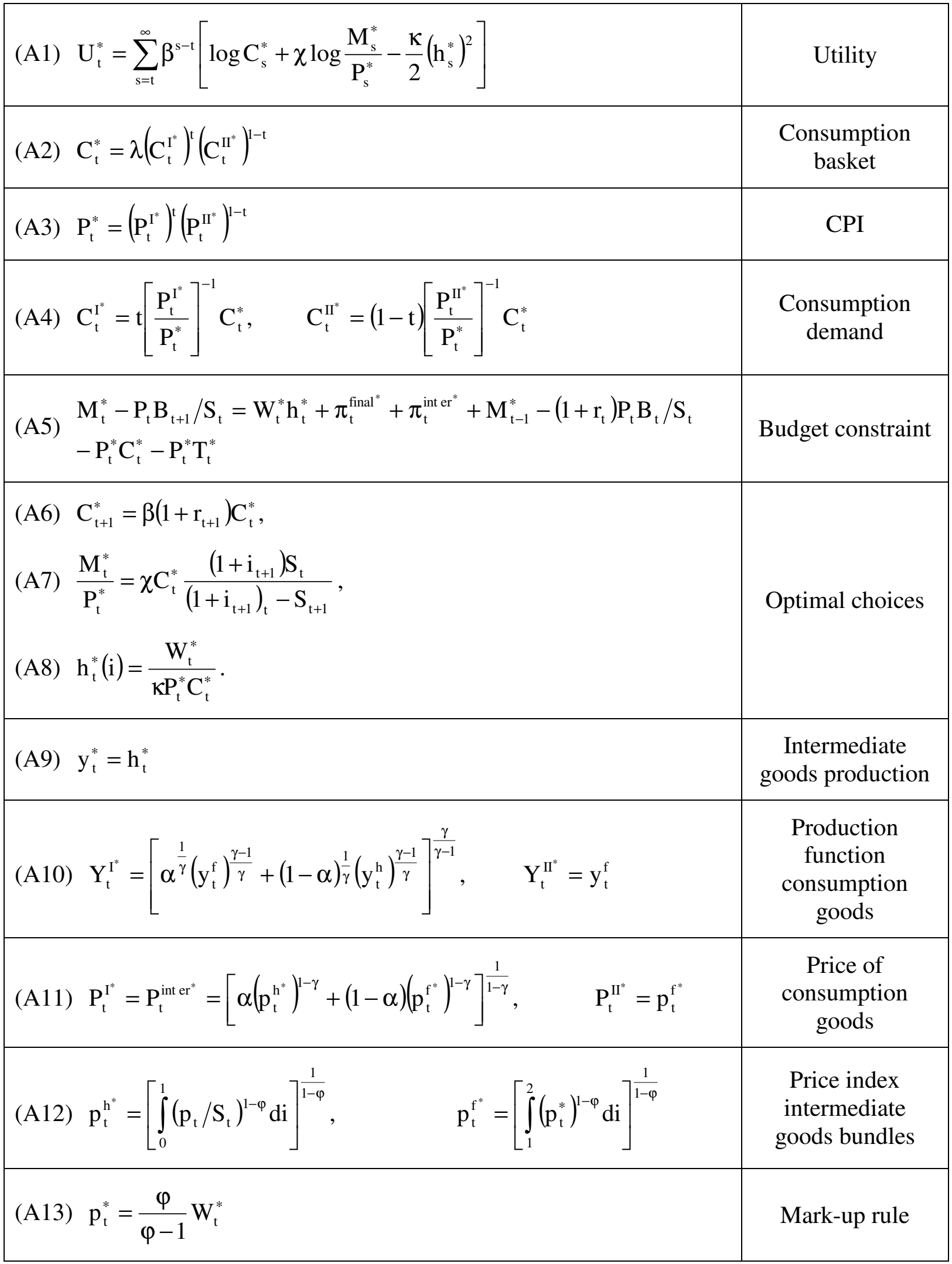




\begin{tabular}{|l|l|}
\hline $\mathrm{y}_{\mathrm{t}}^{*}=\mathrm{t}\left[\frac{\mathrm{p}_{\mathrm{t}}^{*}}{\mathrm{p}_{\mathrm{t}}^{\mathrm{f}^{*}}}\right]^{-\varphi}\left\{\alpha\left[\frac{\mathrm{p}_{\mathrm{t}}^{\mathrm{f}^{*}}}{\mathrm{P}_{\mathrm{t}}^{\text {int er }}}\right]^{-\gamma}\left[\frac{\mathrm{P}_{\mathrm{t}}^{\text {int er }}}{\mathrm{P}_{\mathrm{t}}^{*}}\right]^{-1} \mathrm{C}_{\mathrm{t}}^{*}+(1-\alpha)\left[\frac{\mathrm{S}_{\mathrm{t}} \mathrm{p}_{\mathrm{t}}^{\mathrm{f}^{*}}}{\mathrm{P}_{\mathrm{t}}^{\text {int }}}\right]^{-\gamma}\left[\frac{\mathrm{P}_{\mathrm{t}}^{\text {int er }}}{\mathrm{P}_{\mathrm{t}}}\right]^{-1} \mathrm{C}_{\mathrm{t}}\right\}$ & $\begin{array}{c}\text { Intermediate good } \\
\text { demand }\end{array}$ \\
$+(1-\mathrm{t})\left[\frac{\mathrm{p}_{\mathrm{t}}^{*}}{\mathrm{p}_{\mathrm{t}}^{\mathrm{f}^{*}}}\right]^{-\varphi}\left[\frac{\mathrm{P}_{\mathrm{t}}^{\mathrm{II}^{*}}}{\mathrm{P}_{\mathrm{t}}^{*}}\right]^{-1} \mathrm{C}_{\mathrm{t}}^{*}$ & \\
\hline (A15) $-\mathrm{P}_{\mathrm{t}}^{*} \mathrm{~T}_{\mathrm{t}}^{*}=\mathrm{M}_{\mathrm{t}}^{*}-\mathrm{M}_{\mathrm{t}-1}^{*}$ & $\begin{array}{c}\text { Government } \\
\text { budget constraint }\end{array}$ \\
\hline (A16) $\mathrm{P}_{\mathrm{t}}^{*} \mathrm{C}_{\mathrm{t}}^{*}=\mathrm{y}_{\mathrm{t}}^{*} \mathrm{p}_{\mathrm{t}}^{*}-\mathrm{P}_{\mathrm{t}} \mathrm{B}_{\mathrm{t}-1} / \mathrm{S}_{\mathrm{t}}+\left(1+\mathrm{r}_{\mathrm{t}}\right) \mathrm{P}_{\mathrm{t}} \mathrm{B}_{\mathrm{t}} / \mathrm{S}_{\mathrm{t}}$ & Current account \\
\hline
\end{tabular}

\section{B Table 2: The log-linearized model}

Variables from the initial symmetric steady state are indexed by the subscript " 0 " and percentage deviations from it are denoted by $\tilde{X}_{t}$, where $\tilde{X}_{t}=\left(X_{t}-X_{0}\right) / X_{0}$. The stock of bonds held by home and foreign agents is scaled by nominal consumption, $\widetilde{B}_{t}=\mathrm{dB}_{\mathrm{t}} / \mathrm{C}_{0}$, since we assume that in the initial steady state no country has a net claim on the other one, $\mathbf{B}_{0}=0$. Moreover, the real interest rate is tied down by the Euler equation (10) so that $\mathrm{r}_{0}=(1-\beta) / \beta$.

(B1) $\tilde{\mathrm{C}}_{\mathrm{t}}=\mathrm{t} \widetilde{\mathrm{C}}_{\mathrm{t}}^{\mathrm{I}}+(1-\mathrm{t}) \tilde{\mathrm{C}}_{\mathrm{t}}^{\mathrm{II}}$

(B2) $\tilde{\mathrm{C}}_{\mathrm{t}}^{*}=\mathrm{t} \widetilde{\mathrm{C}}_{\mathrm{t}}^{\mathrm{I}^{*}}+(1-\mathrm{t}) \tilde{\mathrm{C}}_{\mathrm{t}}^{\mathrm{I}^{*}}$

Consumption

(B3) $\tilde{\mathrm{Y}}_{\mathrm{t}}^{\mathrm{I}}=\tilde{\mathrm{C}}_{\mathrm{t}}^{\mathrm{I}}=\tilde{\mathrm{C}}_{\mathrm{t}}+\left[\tilde{\mathrm{P}}_{\mathrm{t}}-\tilde{\mathrm{P}}_{\mathrm{t}}^{\text {inter }}\right], \quad \tilde{\mathrm{Y}}_{\mathrm{t}}^{\mathrm{II}}=\tilde{\mathrm{C}}_{\mathrm{t}}^{\mathrm{II}}=\tilde{\mathrm{C}}_{\mathrm{t}}+\left[\widetilde{\mathrm{P}}_{\mathrm{t}}-\tilde{\mathrm{p}}_{\mathrm{t}}\right]$

(B4) $\tilde{\mathrm{Y}}_{\mathrm{t}}^{\mathrm{I}^{*}}=\widetilde{\mathrm{C}}_{\mathrm{t}}^{\mathrm{I}^{*}}=\widetilde{\mathrm{C}}_{\mathrm{t}}^{*}+\left[\widetilde{\mathrm{P}}_{\mathrm{t}}^{*}-\widetilde{\mathrm{P}}_{\mathrm{t}}^{\mathrm{int} \mathrm{er}^{*}}\right], \tilde{\mathrm{Y}}_{\mathrm{t}}^{\mathrm{II}^{*}}=\widetilde{\mathrm{C}}_{\mathrm{t}}^{\mathrm{II}^{*}}=\widetilde{\mathrm{C}}_{\mathrm{t}}^{*}+\left[\widetilde{\mathrm{P}}_{\mathrm{t}}^{*}-\widetilde{\mathrm{p}}_{\mathrm{t}}^{*}\right]$

Output of consumption goods

(B5)

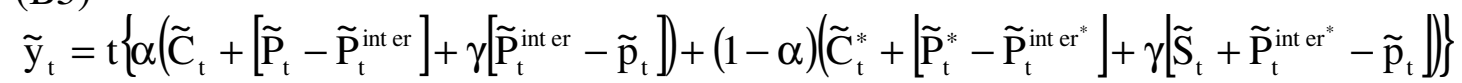
$+(1-\mathrm{t})\left(\widetilde{\mathrm{C}}_{\mathrm{t}}+\left[\tilde{\mathrm{P}}_{\mathrm{t}}-\tilde{\mathrm{p}}_{\mathrm{t}}\right]\right)$

(B6)

$\tilde{\mathrm{y}}_{\mathrm{t}}^{*}=\mathrm{t}\left\{\alpha\left(\tilde{\mathrm{C}}_{\mathrm{t}}^{*}+\left[\tilde{\mathrm{P}}_{\mathrm{t}}^{*}-\widetilde{\mathrm{P}}_{\mathrm{t}}^{\text {int er }}\right]+\gamma\left[\widetilde{\mathrm{P}}_{\mathrm{t}}^{\text {int er }}{ }^{*}-\tilde{\mathrm{p}}_{\mathrm{t}}^{*}\right]\right)+(1-\alpha)\left(\tilde{\mathrm{C}}_{\mathrm{t}}+\left[\widetilde{\mathrm{P}}_{\mathrm{t}}-\widetilde{\mathrm{P}}_{\mathrm{t}}^{\text {int er }}\right]+\gamma\left[\widetilde{\mathrm{P}}_{\mathrm{t}}^{\text {int er }}-\tilde{\mathrm{S}}_{\mathrm{t}}-\tilde{\mathrm{p}}_{\mathrm{t}}^{*}\right]\right)\right\}$ Demand for intermediate goods $+(1-\mathrm{t})\left(\tilde{\mathrm{C}}_{\mathrm{t}}^{*}+\left[\tilde{\mathrm{P}}_{\mathrm{t}}^{*}-\tilde{\mathrm{p}}_{\mathrm{t}}^{*}\right]\right)$ 


\begin{tabular}{|c|c|}
\hline $\begin{array}{l}\text { (B7) } \tilde{\mathrm{C}}_{\mathrm{t}}+\widetilde{\mathrm{P}}_{\mathrm{t}}=\tilde{\mathrm{y}}_{\mathrm{t}}+\tilde{\mathrm{p}}_{\mathrm{t}}+\widetilde{\mathrm{B}}_{\mathrm{t}-1}-\beta \widetilde{\mathrm{B}}_{\mathrm{t}} \\
\text { (B8) } \tilde{\mathrm{C}}_{\mathrm{t}}^{*}+\widetilde{\mathrm{P}}_{\mathrm{t}}^{*}=\tilde{\mathrm{y}}_{\mathrm{t}}^{*}+\tilde{\mathrm{p}}_{\mathrm{t}}^{*}-\widetilde{\mathrm{B}}_{\mathrm{t}-1}+\beta \widetilde{\mathrm{B}}_{\mathrm{t}}\end{array}$ & $\begin{array}{l}\text { Current } \\
\text { account }\end{array}$ \\
\hline $\begin{array}{l}\text { (B9) } \tilde{\mathrm{C}}_{\mathrm{t}+1}=\widetilde{\mathrm{C}}_{\mathrm{t}}+(1-\beta) \tilde{\mathrm{r}}_{\mathrm{t}} \\
\text { (B10) } \widetilde{\mathrm{C}}_{\mathrm{t}+1}^{*}=\tilde{\mathrm{C}}_{\mathrm{t}}^{*}+(1-\beta) \widetilde{\mathrm{r}}_{\mathrm{t}}+\left(\widetilde{\mathrm{S}}_{\mathrm{t}}-\Delta \tilde{\mathrm{P}}_{\mathrm{t}}\right)-\left(\tilde{\mathrm{S}}_{\mathrm{t}+1}-\Delta \widetilde{\mathrm{P}}_{\mathrm{t}+1}\right)\end{array}$ & $\begin{array}{l}\text { Intertemporal } \\
\text { allocation of } \\
\text { consumption }\end{array}$ \\
\hline $\begin{array}{l}\text { (B11) } \tilde{\mathrm{M}}_{\mathrm{t}}-\widetilde{\mathrm{P}}_{\mathrm{t}}=\widetilde{\mathrm{C}}_{\mathrm{t}}-\beta \tilde{\mathrm{r}}_{\mathrm{t}}-(\beta /(1-\beta))\left(\tilde{\mathrm{P}}_{\mathrm{t}+1}-\widetilde{\mathrm{P}}_{\mathrm{t}}\right) \\
\text { (B12) } \tilde{\mathrm{M}}_{\mathrm{t}}^{*}-\widetilde{\mathrm{P}}_{\mathrm{t}}^{*}=\widetilde{\mathrm{C}}_{\mathrm{t}}^{*}-\beta \tilde{\mathrm{r}}_{\mathrm{t}}-(\beta /(1-\beta))\left(\tilde{\mathrm{P}}_{\mathrm{t}+1}-\widetilde{\mathrm{P}}_{\mathrm{t}}+\widetilde{\mathrm{S}}_{\mathrm{t}}-\widetilde{\mathrm{S}}_{\mathrm{t}+1}\right)\end{array}$ & $\begin{array}{l}\text { Money } \\
\text { demand }\end{array}$ \\
\hline $\begin{array}{l}\text { (B13) } \tilde{\mathrm{y}}_{\mathrm{t}}=\tilde{\mathrm{p}}_{\mathrm{t}}-\tilde{\mathrm{P}}_{\mathrm{t}}-\tilde{\mathrm{C}}_{\mathrm{t}} \\
\text { (B14) } \tilde{\mathrm{y}}_{\mathrm{t}}^{*}=\tilde{\mathrm{p}}_{\mathrm{t}}^{*}-\tilde{\mathrm{P}}_{\mathrm{t}}^{*}-\tilde{\mathrm{C}}_{\mathrm{t}}^{*}\end{array}$ & Labor supply \\
\hline $\begin{array}{l}\text { (B15) } \tilde{\mathrm{P}}_{\mathrm{t}}=\mathrm{t} \tilde{\mathrm{P}}_{\mathrm{t}}^{\text {inter }}+(1-\mathrm{t}) \tilde{\mathrm{P}}_{\mathrm{t}} \\
\text { (B16) } \widetilde{\mathrm{P}}_{\mathrm{t}}^{*}=\tilde{\mathrm{P}}_{\mathrm{t}}^{\text {inter }}+(1-\mathrm{t}) \tilde{\mathrm{P}}_{\mathrm{t}}^{*}\end{array}$ & CPI \\
\hline $\begin{array}{l}\text { (B17) } \tilde{\mathrm{P}}_{\mathrm{t}}^{\text {inter }}=\alpha \tilde{\mathrm{p}}_{\mathrm{t}}+(1-\alpha)\left(\tilde{\mathrm{p}}_{\mathrm{t}}^{*}+\widetilde{\mathrm{S}}_{\mathrm{t}}\right) \\
(\mathrm{B} 18) \widetilde{\mathrm{P}}_{\mathrm{t}}^{\text {inter }}=\alpha \tilde{\mathrm{p}}_{\mathrm{t}}^{*}+(1-\alpha)\left(\tilde{\mathrm{p}}_{\mathrm{t}}-\widetilde{\mathrm{S}}_{\mathrm{t}}\right)\end{array}$ & $\begin{array}{l}\text { Price index } \\
\text { intermediate } \\
\text { goods }\end{array}$ \\
\hline
\end{tabular}

\section{Table 3: Solutions for the long run dependent on $\bar{B}$}

(C1) $\Delta \overline{\mathrm{C}}=\frac{1+2[(1-\mathrm{t})(1-\alpha)+\alpha \gamma]}{2 \alpha(\gamma-1)+1}(1-\beta) \overline{\mathrm{B}}$

(C2) $\overline{\mathrm{C}}=\frac{1}{2} \frac{1+2[(1-\mathrm{t})(1-\alpha)+\alpha \gamma]}{2 \alpha(\gamma-1)+1}(1-\beta) \overline{\mathrm{B}}$

(C3) $\overline{\mathrm{C}}^{*}=-\frac{1}{2} \frac{1+2[(1-\mathrm{t})(1-\alpha)+\alpha \gamma]}{2 \alpha(\gamma-1)+1}(1-\beta) \overline{\mathrm{B}}$

(C4) $\Delta \bar{y}=-(1-\beta) \bar{B}$ 
(C5) $\bar{y}=-.5(1-\beta) \bar{B}$

(C6) $\overline{\mathrm{y}}^{*}=.5(1-\beta) \overline{\mathrm{B}}$

(C7) $\bar{\tau}=\frac{1-\mathrm{t}(1-\alpha)}{\mathrm{t}(1-\alpha)(2 \alpha(\gamma-1)+1)}(1-\beta) \overline{\mathrm{B}}$ 


\section{References}

Bacchetta, P. and E. van Wincoop (2002), A Theory of the Currency Denomination of International Trade, NBER Working Paper 9039, Cambridge, MA.

Backus, D., P. Kehoe and F. Kydland (1994), Dynamics of the Trade Balanceand the Terms of Trade: The J-Curve?, American Economic Review 84, 84-103.

Benigno, P. (2001), Price Stability with Imperfect Financial Integration, CEPR Discussion Paper 2854, London.

Benigno, P. (2002), A Simple Approach to International Monetary Policy Coordination, Journal of International Economics 57, 177-196.

Betts, C. and M. Devereux (1996), The Exchange Rate in a Model of Pricing-to-Market, European Economic Review 40, 1007-1021.

Betts, C. and M. Devereux (2000), Exchange Rate Dynamics in a Model of Pricing-toMarket, Journal of International Economics 50, 215-244.

Campa, J. and L. Goldberg (2002), Exchange Rate Pass-Through into Import Prices: A Macro or Micro Phenomenon?, NBER Working Paper 8934, Cambridge, MA.

Chari, V., P. Kehoe and E. McGrattan (2002), Can Sticky Price Models Generate Volatile and Persistent Real Exchange Rates? Review of Economic Studies 69, 533-563.

Corsetti, G. and P. Pesenti (2001a), Welfare and Macroeconomic Interdependence, Quarterly Journal of Economics 116, 421-446.

Corsetti, G. and P. Pesenti (2001b), International Dimensions of Optimal Monetary Policy, NBER Working Paper 8230, Cambridge, MA.

Engel, C. (2002), Expenditure Switching and Exchange Rate Policy, NBER Working Paper 9016, Cambridge, MA.

Engel, C. and J. Rogers (1996), How Wide is the Border? American Economic Review 86, 1112-1125.

Goldberg, P. and M. Knetter (1997), Goods Prices and Exchange Rates: What Have We Learned? Journal of Economic Literature 35, 1243-1272.

Goldberg, P. and M. Knetter (1998), Measuring the Intensity of Competition in Export Markets, Journal of International Economics 47, 27-60.

Hau, H. (2000), Exchange Rate Determination: The Role of Factor Price Rigidities and Nontradeables, Journal of International Economics 50, 421-447.

McCarthy, J. (1999), Pass-Through of Exchange Rates and Import Prices to Domestic Inflation in Some Industrialized Economies, BIS Working Paper No. 79, Basle.

Michaelis, J. (2002), Monetary Policy: Prosper-thy-neighbor and Beggar-Thyself? Working Paper, University of Kassel, Kassel. 
Obstfeld, M. (2001), International Macroeconomics: Beyond the Mundell-Fleming Model, IMF Staff Papers 47, 1-39.

Obstfeld, M. and K. Rogoff (1995), Exchange Rate Dynamics Redux, Journal of Political Economy 103, 624-660.

Obstfeld, M. and K. Rogoff (1996), Foundations of International Macroeconomics, MIT Press, Cambridge, MA.

Obstfeld, M. and K. Rogoff (2000), New Directions for Stochastic Open Economy Models, Journal of International Economics 50, 117-153.

Obstfeld, M. and K. Rogoff (2002), Global Implications of Self-Oriented National Monetary Rules, Quarterly Journal of Economics 117, 503-536.

Parsley, D. and S. Wei (2001), Explaining the Border Effect: The Role of Exchange Rate Variability, Shipping Costs, and Geography, Journal of International Economics 55, 87-105.

Sutherland, A. (2002), International Monetary Policy Coordination and Financial Market Integration, European Central Bank Working Paper No. 174, Frankfurt am Main.

Tille, C. (2000), "Beggar-thy-neighbor" or "Beggar-thyself”? The Income Effect of Exchange Rate Fluctuations, FRBNY Staff Report 112, Federal Reserve Bank of New York, New York.

Tille, C. (2001), The Role of Consumption Substitutability in the International Transmission of Shocks, Journal of International Economics 53, 421-444.

Warnock, F. (2003), Exchange Rate Dynamics and the Welfare Effects of Monetary Policy in a Two-Country Model with Home-Product Bias, Journal of International Money and Finance 22, 343-363. 